\title{
EMPOWERMENT, TRAINING, AND WORKSHOP OF VERTICAL GARDEN AS GREEN IN THE SPRING LAND IN RT 01-09 / RW04, TUGU SELATAN VILLAGE, KOJA, NORTH JAKARTA
}

\author{
Sri Kurniasih, Inggit Musdinar, Dody Kurniawan \\ Universitas Budi Luhur, Indonesia. \\ sri.kurniasih@budiluhur.ac.id
}

\begin{abstract}
The phenomenon of urban areas in Indonesia today tends to experience a typical problem, namely the high rate of population growth mainly due to the flow of urbanization so that the management of urban space becomes heavier. The high number of urban population that continues to increase from time to time has implications for the high pressure on the use of urban space, so that the spatial planning of urban areas needs special attention, especially those related to the provision of residential areas, public and social facilities and spaces open public in urban areas. In general, public open spaces in urban areas consist of green open spaces and non-green open spaces. Urban Green Open Space is part of open spaces of an urban area filled with plants, plants and vegetation (endemic and introduced) to support ecological, socio-cultural and architectural benefits that can provide economic benefits (welfare) for the community. Communities in urban areas are heterogeneous with heterogeneous educational backgrounds as well as environmental conditions in the RT. 05 RW. 04 Tugu Selatan Village, Koja Subdistrict, North Jakarta, where the condition of the land is narrow at each resident's house, so the provision of reforestation is not a top priority for them. RT community problems. 05 RW. 04 Tugu Selatan Village, Koja Subdistrict, North Jakarta at the moment is the lack of public knowledge about the concept of environmentally friendly settlements, which can be realized by providing reforestation on narrow land with vertical gardens.
\end{abstract}

The facilitation and utilization of vertical gardens as greening on narrow land in Jakarta is carried out with the aim of increasing people's understanding of the concept of environmentally friendly settlements through the application of vertical gardens as a form of greening on narrow land and assisting the community in applying vertical gardens on narrow land.

With the application of the concept of Tri Daya in the activities of Assistance and Utilization of Vertical Garden as Greening on Narrow Land in Jakarta, the implementation of community service activities through the licensing stage to the local RW and RT for the implementation of community service activities, survey of target community locations to obtain community service data to the community, coordinating with the local RT and RW to organize this training activity, training in the use of vertical gardens for greening, preparation of community service activities at Budi Luhur University, vertical garden utilization workshops for greening and monitoring the results of making vertical gardens in target communities. As a result of this activity, the community has better understood the reforestation that can be carried out in a narrow area, the community can apply the creation of a vertical garden using simple tools and materials. So that the target people can easily practice themselves in their homes.

Keywords: Empowerment, Urban Society, Greening, Vertical Garden, Narrow Land.

\section{INTRODUCTION}

Settlement is housing with all the contents and activities in it. Housing is a physical container while the settlement is a combination of the container with its contents, which are people who live with all their social characteristics and cultural attributes. With a place of settlement, people and communities are active in society and culture. Settlement can't be separated from the human life that inhabits it. Environmentally friendly settlements are settlements that do not damage the surrounding natural environment or a program that does not cause adverse or negative impacts on the surrounding environment. In environmentally friendly settlements, there are several environmentally friendly concepts, such as environmentally friendly technology, environmentally friendly products, environmentally friendly energy and so on. The environmentally friendly concepts that can be applied in settlements and related to the field of architecture are environmentally friendly products.

The manifestation of environmentally friendly settlements is one of them by preserving the beautiful environment through reforestation, but reforestation efforts on sufficiently large land will be different from reforestation where the land is not so broad or narrow. Land settlements in urban areas, especially in the city of 
North Jakarta tend to be narrow. One greening solution that can be applied on narrow land is greening vertically or commonly called a vertical garden. Communities in urban areas are heterogeneous with heterogeneous educational backgrounds as well as environmental conditions in the RT. 05 RW. 04 Tugu Selatan Village, Koja Subdistrict, North Jakarta, where the condition of the land is narrow at each resident's house, so the provision of reforestation is not a top priority for them. Thus it is necessary to have an activity that can foster awareness of the importance of greening and increase community insight and creativity, then the idea of the activity "Facilitation and Utilization of Vertical Garden as Greening on Narrow Land in Jakarta".

\section{A. The Problem}

The community problems in RT 05 RW 04 Tugu Selatan Village, Koja Subdistrict, North Jakarta at this time is the lack of public knowledge about the concept of environmentally friendly settlements, which can be realized by providing reforestation on narrow land with a vertical garden, it is necessary to have a socialization and assistance that can open a window of community insights so that can apply the provision of reforestation on narrow land.

\section{B. Target}

As a solution to the problems of the RT community. 05 RW. 04 Tugu Selatan Urban Village, Koja Subdistrict, North Jakarta, the resulting output target is for the community to know and realize environmentally friendly settlements through the creation and application of vertical gardens as a greening solution in a narrow area.

\section{GENERAL DESCRIPTION OF TARGET COMMUNITIES}

\section{A. Regional Profile of Tugu Selatan Village}

The total area of South Tugu Village is $186 \mathrm{~km} 2$, consisting of 4,062 families (KK), $52 \mathrm{RT}$ and 4 RW. The boundaries of South Tugu Village are as follows:

North: bordering the Plumpang-Semper road, North Tugu Village Office.

South: bordering Kali Batik Dam, Pegangsaan Villagedua.

East: bordering the Kali Cakung Lama, West Semper Village.

West: bordering Kali Bendungan Melayu, VillageRawa Badak Selatan.

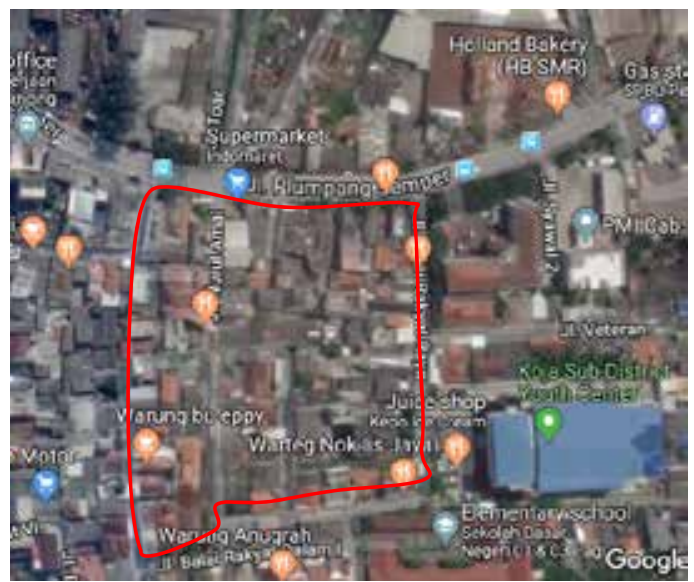

Picture 1. RT location. 05 RW. 04 VillageTugu Selatan, Koja Subdistrict, North Jakarta Source: https://www.google.com/maps/@ 6.1318472,106.9136131,228m/data=!3m1!1e3?hl=en-US, April 2019

\section{B. Environmental Conditions RT. 05 Rw. 04 VillageTugu Selatan}

The low awareness of the community in providing reforestation as water absorption in the RT environment. 05 RW. 04 Tugu Selatan Village, so the settlements and corridors look not beautiful. 

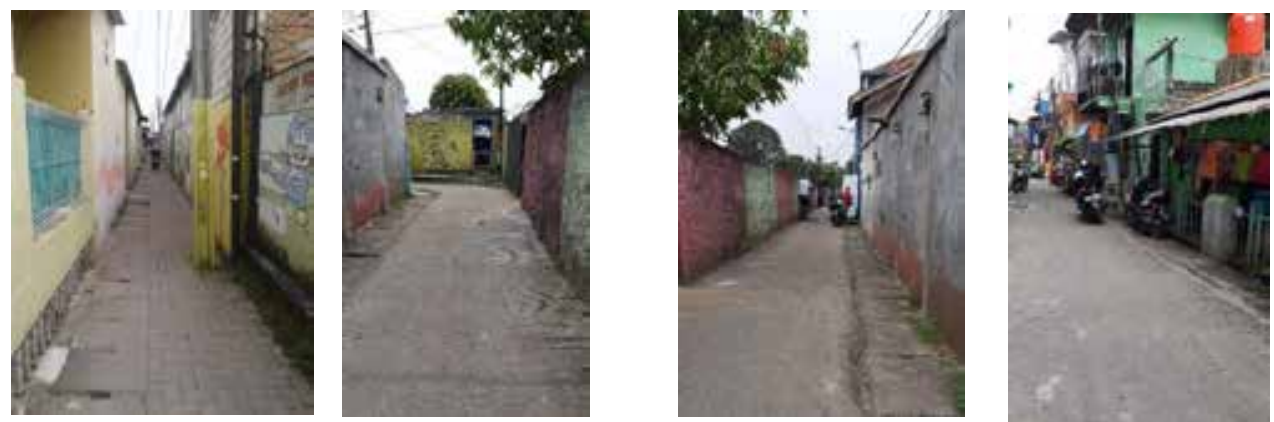

Picture 2. Conditions of settlements in RT. 05 RW. 04 Kelurahan Tugu Selatan, Koja Subdistrict, North Jakarta

Source: Observation results

\section{METHOD OF COMMUNITY SERVICE}

\section{A. Methods and Stages of Community Service Activities}

To plunge directly into the community in an effort to implement Community Assistance Towards Eco-Friendly Settlements in RT. 05 RW. 04 Tugu Selatan Village, Koja Subdistrict, North Jakarta, an approach process with the TRI-DAYA concept is needed.

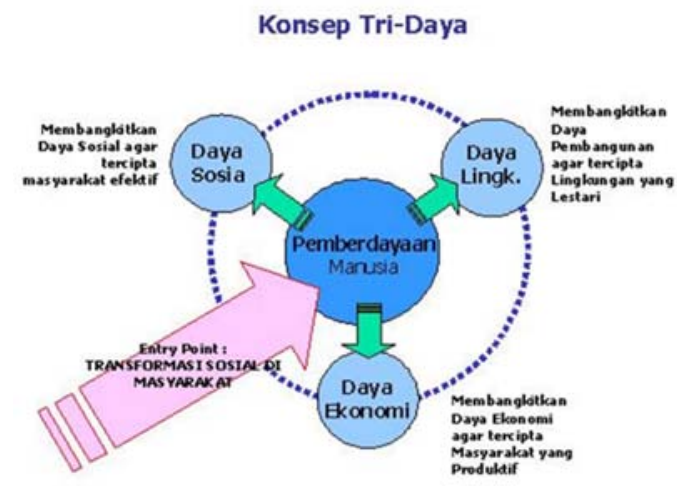

Picture 3. Tri Daya Concept Chart

\section{B. Social Power}

The concept of Social Power is to invite the community through the activities of Assistance and Utilization of Vertical Gardens as Greening on Narrow Land in Jakarta on RT. 05 RW 04 Tugu Selatan sub-district in providing greening to the environment.

The concept of empowering people to care about waste through:

1. Knowledge of green open space and the benefits of greening the environment.

2. Knowledge of the manufacture and supply of vertical gardens.

\section{Environmental Power}

The concept of Environmental Power is to identify:

1. Community ignorance of the green environment.

2. The ability of the community to plant crops.

3. The ability of the community environment in providing planting media.

\section{Economic Power}

The concept of Economic Power is the result of the production of making vertical gardens that can be used alone or sold to the general public, which in turn can increase the economic value of the surrounding community. By utilizing the vertical garden as a greening with good and right can cool the ambient air temperature.

\section{E. Partner Participation}

During the implementation of the activity, the Partner participates in the implementation of the program, from the beginning to the end.

a. In the initial stages of licensing the implementation of the partner program participates in: 
- $\quad$ Provide information about problems faced by partners.

- Give permission to the Budi Luhur University Architecture Study Program to conduct field studies in partner regions.

- Sign licensing of service activities at partner locations.

b. During the application phase of the vertical garden training accompaniment application, partners participate in:

- Helps socialize activities to the local community.

- $\quad$ Provide a place for the implementation of activities.

- $\quad$ Provide work equipment to make a vertical garden.

c. In the final stage, reporting the results of program implementation to partners.

- Give permission to the Budi Luhur University Architecture Study Program to monitor the sustainability of the program's implementation.

\section{RESULT}

The results of Community Service activities by the Architecture Study Program, Faculty of Engineering, Budi Luhur University in the form of socialization, training, and monitoring of the use of Vertical gardens for greening in limited land for the RT community. 05 RW. 04 Kelurahan Tugu Selatan, Koja Subdistrict, North Jakarta.

\section{A. Location Suvey Activity, Licensing, and Socialization}

The activity began with a site survey, requesting permission from the local village office, and socialization regarding the implementation of activities to the RT residents. 05 RW. 04 Kelurahan Tugu Selatan, Koja Subdistrict, North Jakarta. From the results of this site survey, an agreement was reached on the day of the training activities and the target community members to be included. And the Vertical Garden Training was agreed on Wednesday, July 17, 2019.

\section{B. Vertical garden Utilization Training Activities for Greening}

Vertical garden training activities at the South Tugu Citizens' Hall are divided into 2 sessions, namely:

1. Submission of Material about Vertical garden

The activity began with the presentation of material about Green Open Space. This material as an opening material, and also an introduction to green open space, its benefits and also the application of greening with a vertical garden.

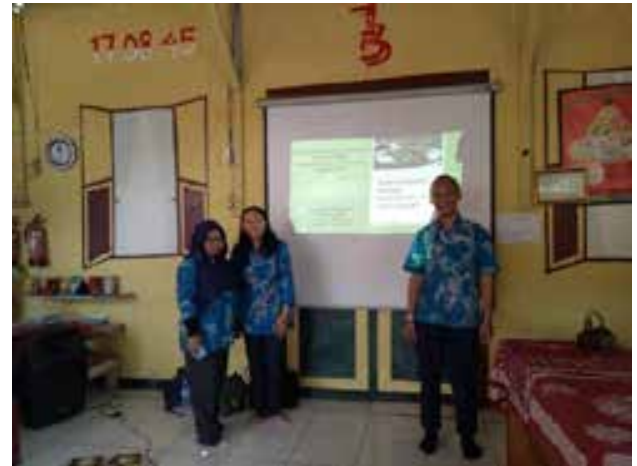

Picture 4. Submission of Vertical Garden Material at the Community Hall

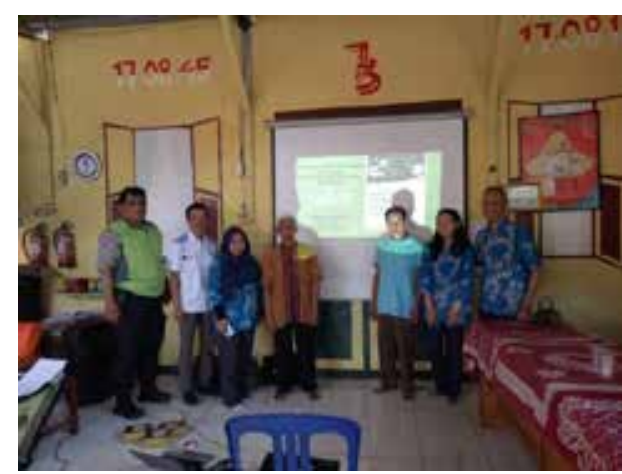

Picture 5. Photo session with South Tugu Village Village Official

\section{Practice making Vertical garden mock-ups}

After following the presentation of material about Vertical garden for greening, continued with the practice of making Vertical garden mock-ups. Vertical gardens can be made using boards which are then fitted with harmonica wire and residents are directed to move the plants provided in pots, fill with planting media and arrange them in vertical garden boards. 


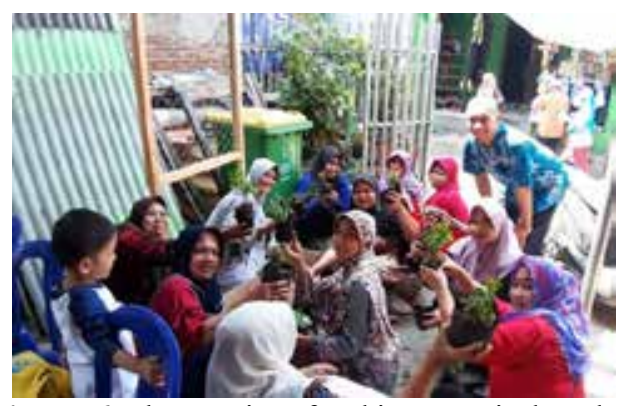

Picture 6. The practice of making a vertical garden.

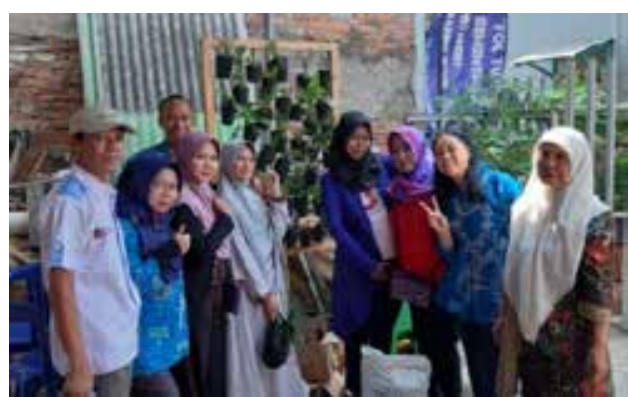

Picture 8. Group photo with the residents and the finished Vertical Garden.

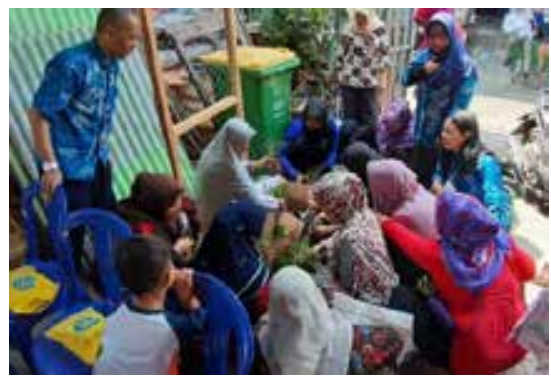

Picture 7. Transfer of Plants from Polybags to Vertical Garden pots

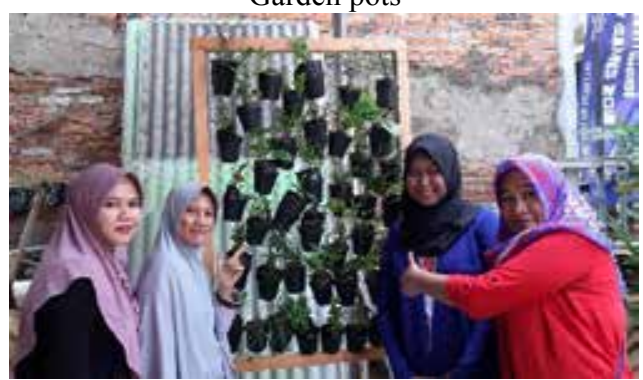

Picture 9. The finished of Vertical Garden.

\section{Monitoring the Implementation of Vertical Gardens in Target Citizens}

The next activity of the Vertical garden training is monitoring and giving appreciation to residents who have received training and implemented a vertical garden in their homes.

1. Application of Vertical garden in Mrs. $\mathrm{Hj}$. Ani
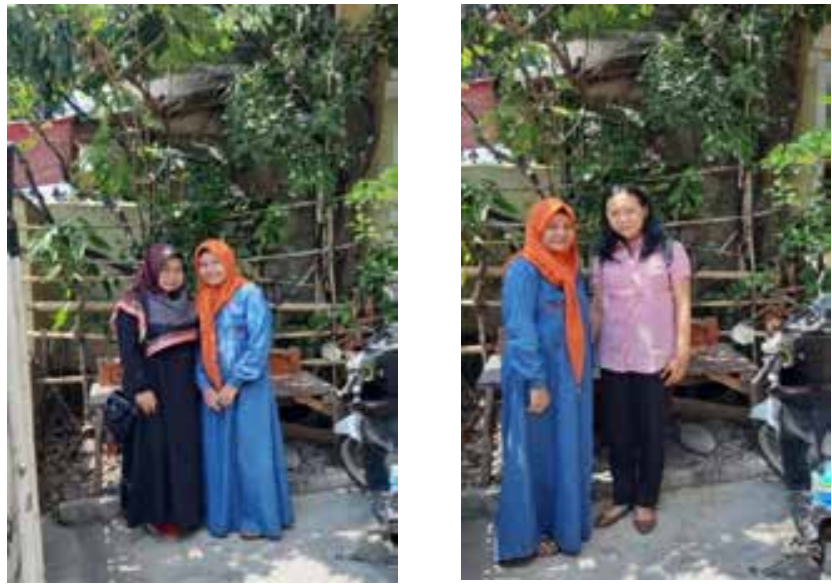

Picture 10. Vertical Garden with bamboo slats at Mrs. Hj. Ani

2. Application of Vertical garden at Mrs. Suparmi's home
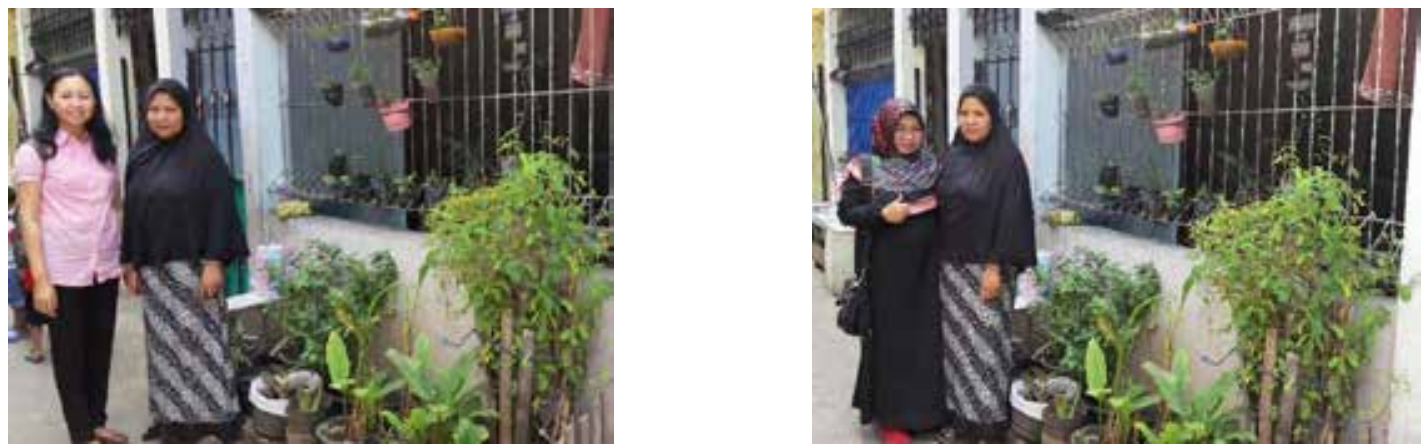

Picture 11. Vertical Garden with bamboo slats at Ibu Suparmi's Home 
3. The application of a vertical garden in Mrs. Sumarni's house
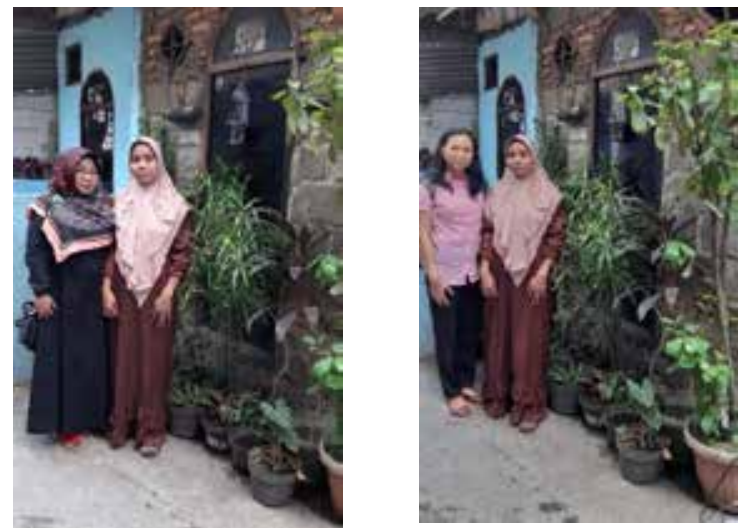

Picture 12. Vertical Garden with bamboo slats at Ibu Sumarni's House

\section{CONCLUSIONS AND SUGGESTIONS}

\section{A. Conclusion}

Vertical garden utilization training for greening that has been carried out with RT residents. 05 RW. 04 Tugu Selatan Village, Koja Subdistrict, North Jakarta, can be done easily and uses simple equipment. So that the target people can easily practice themselves in their homes. Equipment needed includes a vertical garden board, readyto-hang pots, planting media, and plants of various types. Or it can even be done with used items such as plastic bottles, bamboo slats, and so on. Thus it can be concluded that making a vertical garden for greening is very easy to do by anyone.

\section{B. Suggestion}

Community Service Activities by the Architecture Study Program Lecturer Team, Faculty of Engineering, Budi Luhur University in the form of Vertical Garden Utilization Training for greening for RT residents. 05 RW. 04 Tugu Selatan Village, Koja Subdistrict, North Jakarta received positive responses from local residents. So this kind of activity needs to be transmitted to other urban village residents. In addition, similar training can be developed which can provide economic value, for example with Urban farming or hydroponics training.

\section{REFERENCES}

Suryandari, Putri; Dyah, Anggraeni dan Kurniasih Sri. 2017. IbM Menuju Kampung Petani Sampah di Kampung Belakang Kelurahan Kamal Kecamatan Kalideres Jakarta Barat. Laporan PKM. Universitas Budi Luhur Jakarta.

Kurniasari, Netty Dyah. 2015. Program CSR Berbasis Pemberdayaan Masyarakat (Untuk meningkatkan Produktivitas Usaha Mikro, Kecil, Menengah di Madura). Jurnal NeO Bis. Volume 9 No.1 2015.

Sugiyono. 2011. Metode Penelitian Kuantitatif, Kualitatif, dan R \& D. Bandung: Alfabeta.

Perkotaan, PNPM Mandiri. Pedoman Teknis Kegiatan Tri Daya (Sosial, Ekonomi, dan Lingkungan), Direktorat Jenderal Cipta Karya - Kementerian Pekerjaan Umum. 